\title{
Improving nutrient and water use efficiencies in multi-loop aquaponics systems
}

\author{
Simon Goddek ${ }^{1}$ (D) $\cdot$ Karel J. Keesman ${ }^{1}$
}

Received: 26 March 2020 / Accepted: 27 August 2020 / Published online: 12 September 2020

(C) The Author(s) 2020

\begin{abstract}
The sustainable development of agricultural systems where nutrients and water are recycled to a high degree is of enormous importance. Traditional aquaponics, where fish and plants are cultivated in one recirculating system, addresses these ecological challenges, but still struggles with its economical feasibility. Decoupled multi-loop aquaponics systems, in which the aquaculture and hydroponics subsystems are running autonomously, proved that they can keep up with the productivity of state-of-the-art hydroponics systems or even outscore them. Yet, a problem of such decoupled aquaponics systems was that plants require a high nutrient concentration, whereas fish prefer rather a clean water. In practice, the opposite is happening as the nutrients are added to the aquaculture units through the feed. This paper optimizes a recent approach showing that desalination technologies, such as reverse osmosis, can play an important role in reversing the concentrations within such systems without killing beneficial plant growth-promoting rhizobacteria thermally. The proposed integrated systems approach has the potential to make both periodical nutrient and water discharges and excessive fertilizer supplementation obsolete that would otherwise be necessary to maintain good water quality for the fish and an optimal nutrient solution for the plants.
\end{abstract}

Keywords Aquaponics · Desalination · Nutrient recovery · Decoupled aquaponics · Horticulture · Sustainability $\cdot$ Sustainable agriculture

This article is part of the Topical Collection on Aquaponics and Biofloc

Simon Goddek

simon.goddek@wur.nl

Karel J. Keesman

karel.keesman@wur.nl

1 Mathematical and Statistical Methods (Biometris), Wageningen University, P.O. Box 16, 6700

AA Wageningen, The Netherlands 


\section{Introduction}

Aquaponics is the process of growing aquatic organisms and plants symbiotically in one system or several subsystems (Lennard and Leonard 2006; Monsees et al. 2017b; Yep and Zheng 2019), whereas the process water is recirculated freely between the aquaculture and hydroponics units in one-loop systems (Palm et al. 2019); decoupled multi-loop aquaponics systems follow a different approach. Decoupled aquaponics systems separate the aquaculture and hydroponics units from each other so that optimal conditions (i.e., temperature, $\mathrm{pH}$, nutrient concentration, etc.) for both fish and plant can be achieved (Goddek et al. 2016; Kledal and Thorarinsdottir 2018; Kloas et al. 2015). Advantages of decoupled aquaponics systems is a higher water and nutrient use efficiency and presumably higher yields compared with the traditional approach and stand-alone hydroponics systems (Delaide et al. 2016; Dijkgraaf et al. 2019; Goddek and Vermeulen 2018; Nicoletto et al. 2018; Nozzi et al. 2018; Saha et al. 2016). However, this tendentious effect was mainly being observed when growing leafy vegetables and does not apply for all crops. On the other hand, an issue of closed hydroponics systems is that salts tend to accumulate. Periodical discharges of the nutrient solution are thus required (Carmassi et al. 2005; Savvas et al. 2008). Recent publications showed that a nutrient solution based on aquaculture water increased the uptake of salts and might make such discharges obsolete (Delaide et al. 2017; Goddek and Vermeulen 2018).

Since the nutrients enter aquaponics systems mainly via the fish feed, nutrients consequently accumulate in the recirculating aquaculture system (RAS) (Espinal and Matulić 2019; Lekang 2007; Timmons and Ebeling 2013). This is especially the case for decoupled aquaponics systems, where the nutrient flow solely is one way; i.e., from the RAS to the hydroponics subsystem (Kloas et al. 2015; Monsees et al. 2017b). As stated above, plants require a much higher nutrient concentration than fish. So in simple decoupled aquaponics systems, nutrient supplementation is required for the plants, while RAS water needs to be discharged under certain conditions which are mainly fish species-dependent. Consequently, simple decoupled aquaponics systems do not allow favorable water and nutrient use efficiencies, unless processes are integrated that could help to overcome these drawbacks (Goddek et al. 2019).

With respect to system's nutrient use efficiency, several scholars have suggested treating the RAS residual stream, i.e., fish sludge, and processing it further into biofertilizer by using bioreactor technology (Delaide et al. 2019a, b; Goddek et al. 2018; Monsees et al. 2017a). In order to concentrate nutrients in the hydroponics system, and enhancing water quality on the fish side, Goddek and Keesman (2018) recently introduced a process that deals with solving this nutrient distribution issue. The objective of this study is to investigate different desalination processes as well as exploring system solutions to optimize the use of desalination technologies for multi-loop aquaponics systems.

\section{Methodology}

Desalination technologies aim to lower or completely remove the salt content from a solvent. In many of these technologies, a water stream with some salt content is split into a brine stream (concentrate) and a desalinated stream (diluate). As desalination typically requires large amounts of energy, currently the focus is more and more on sustainable desalination technologies with the use of renewable energy sources and energy recovery. 
Based on the previous mass balance study of this paper's authors (Goddek and Keesman 2018), this study will examine alternative technologies with respect to (solar) distillation for concentrating nutrients in multi-loop aquaponic systems and explore solutions to reduce energy requirements and monetary expenses by following a process-based approach. As large-scale aquaponic systems are being built, no experimental data is available yet and thus in this study, we explore different solutions to the nutrient concentration problem by following a system-thinking approach.

\section{Alternative nutrient concentrating technologies}

Desalination based on evaporation to produce freshwater from saline water is known and explored for many centuries. Large-scale desalination was implemented in the nineteenth century (Birkett 1984). Initially, multiple-effect distillation (MED), with specific energy consumption (SEC) in the range of $19-27 \mathrm{kWh} / \mathrm{m}^{3}$, was the dominant technology (AlKaraghouli and Kazmerski 2012). However, roughly in the second half of the twentieth century, thermal multi-stage flash distillation (MSF), with an SEC of 20-37 kWh/m 3 , was commonly used (Al-Shammiri and Safar 1999; Van der Bruggen and Vandecasteele 2002). These distillation technologies were and still are commonly used in the Middle East, as the abandoned presence of fossil fuels does not limit the energy needs. In the 1950s, electrodialysis (ED) for demineralization of saline water was introduced, as ion-selective membranes with low electrical resistance became available (Juda and McRae 1950; Wilson 1960). In the late 1960s, large-scale reverse osmosis (RO), with an SEC of $1.8-5.5 \mathrm{kWh} / \mathrm{m}^{3}$, was introduced and in the 1980s RO became a competitive technology with respect to the thermal-based distillation technologies (see Fig. 1) (Bartman et al. 2010; Karabelas et al. 2018).

In the Middle East, the distillation technologies remain popular, as in this region, salinity, temperature, and membrane fouling potential are high and thus limit the application of RO (Greenlee et al. 2009). However, in the rest of the world, RO is the dominant desalination technology. Other technologies, with/without modifications or combination of technologies, are being tested and implemented on small scale. Table 1 shows a non-exhaustive overview of basic desalination technologies, with the most commonly used technologies in bold.

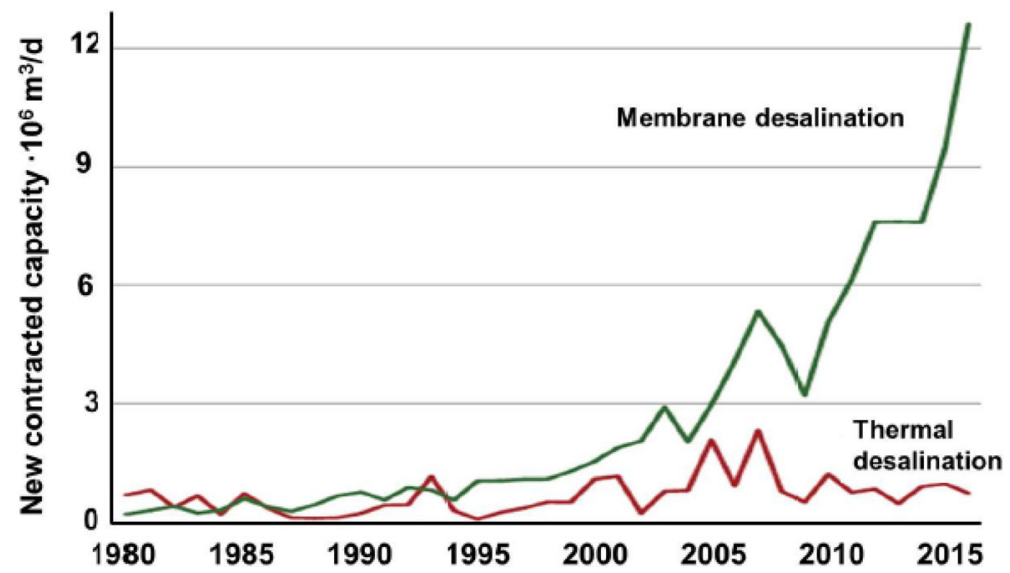

Fig. 1 Past and expected annual growth of the membrane and thermal desalination market. (Source: Fried and Serio 2012) 


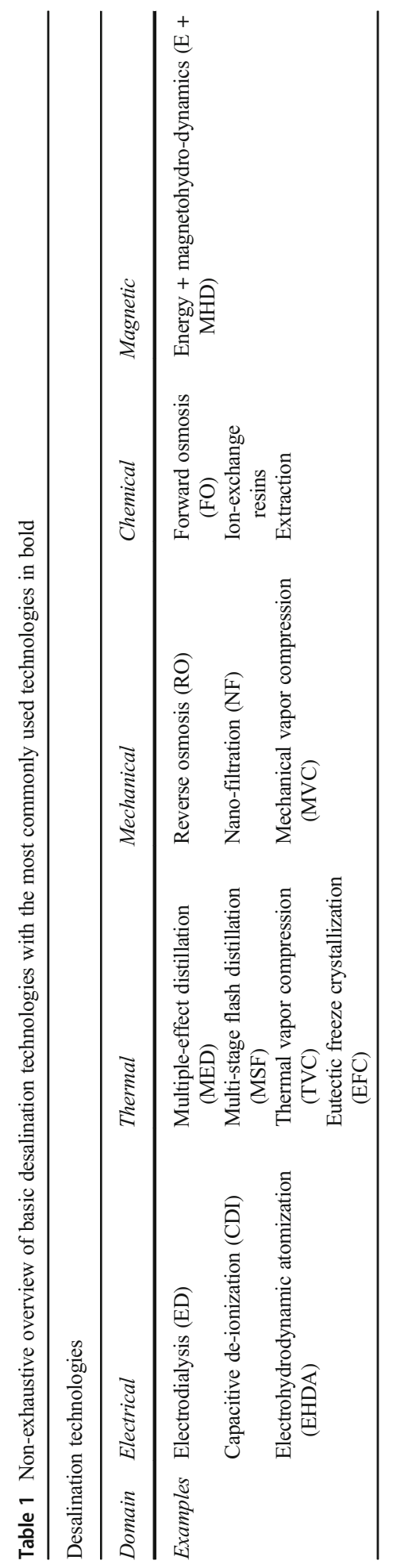


Scale inhibitors, also known as antiscalants and frequently used in RO technologies, prevent the formation of all kinds of scales, which are mainly composed of calcium carbonate, magnesium hydroxide, and calcium sulfate. Generally, antiscalants are organic compounds. Typically, these compounds contain sulphonate, phosphonate, or carboxylic acid functional groups and chelating agents such as carbon, alum, and zeolites (Singh 2005). Especially phosphonate-based antiscalants are of interest here, as these, after possible biodegradation in the rhizosphere (Fisher 2009), might be used as fertilizer for the plants in the hydroponics system. Also, phosphonate-based antiscalants can be removed and partially recovered from membrane concentrates (Boels et al. 2012; Chen et al. 2017).

\section{Process optimization}

Goddek and Keesman (2018) presented one option, based on thermal desalination technologies, to concentrate the hydroponics nutrient solution and leading the demineralized water back to the aquaculture system. The nutrient and water mass balance in this manuscript remains the same. However, the approach presented in the 2018 paper is very energyintensive and would require one desalination unit per hydroponic subsystem (Fig. 2), even though alternative desalination techniques were used.

Another downside of the suggested concept is that the thermal treatment would neutralize beneficial bacteria that are found in the aquaculture process water. The solution that we aim for has to comply with the following conditions: (a) keep the beneficial bacterial alive; (b) be able to serve several hydroponics subsystems; and (c) increase the nutrient and water use efficiency of the overall system.

Unlike a thermal solution, reverse osmosis technology remains the integrity of the bacteria. Figure 2 shows a systemic decoupled aquaponics design taking the abovementioned conditions into account. Compared with the process scheme in Fig. 1, the inflow direction of the nutrient concentrator has been reversed. Instead of increasing the concentration of each hydroponics sump, the revised design aims at extracting and concentrating nutrients from the aquaculture system and leading back demineralized water. This inverted process flow has no effect on the system's mass balance as described by Goddek and Keesman (2018). Instead, a larger desalination unit is required to handle higher inflow capacities. This is due to the fact that the nutrient concentration in the RAS water is much lower than in the hydroponics sump.

Another change contributing to the process optimization is the implementation of protein skimmers (labeled as "prot. Skim" in Fig. 3) (Lekang 2007; Timmons and Ebeling 2013). Protein skimmers remove micro- and nano-particles from the process water. This is in particular important as follows: (1) the inflow water to the RO system should be particlefree to avoid clogging and wearing of the membrane, and (2) to make sure that the water getting into the hydroponic sump only contains soluble nutrients and does not contain particles as these might accumulate in the plants' rhizosphere, potentially leading to a decreased nutrient uptake.

\section{Discussion}

A challenge for food production systems for the future is to achieve and maintain a high water and nutrient use efficiency (Campbell et al. 2016; Howden et al. 2007; Vermeulen et al. 2012). 


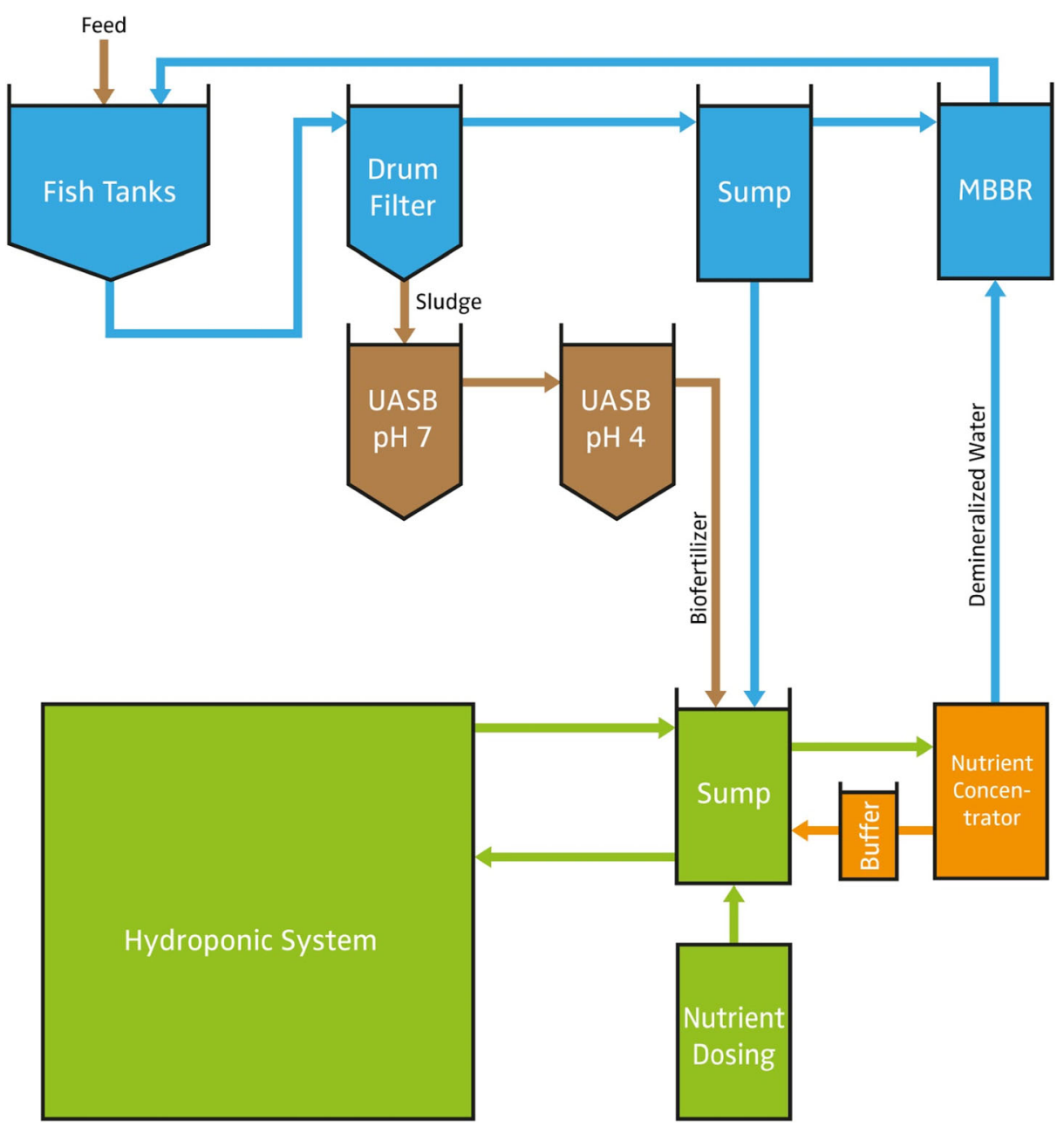

Fig. 2 Aquaponics system with a nutrient concentrator (orange), bioreactors (brown), RAS system (blue), and hydroponic subsystem (green) as suggested by Goddek and Keesman (2018). One desalination/distillation unit is linked to each hydroponic sump

Technical system solutions and advancements are necessary to promote innovation. In our case, we combined several available technologies with a high technology readiness level (TRL) to solve practical problems. As for Fig. 2, we assume the cultivation of tilapia. Cultivating tilapia in stand-alone RAS usually means that around $12 \%$ of the RAS water needs to be discharged to maintain the required water quality. Apart from the fact that both nutrients and water are lost and also nutrient-rich feces are discharged that way, this is a common practice in the RAS industry (Timmons and Ebeling 2013). From our point of view, the sustainable development of farming and food industries requires a high degree of circular flows.

So far, the problem of decoupled aquaponics systems is that nutrients tend to accumulate in the RAS part and are rather scarce in the hydroponics system. From a mass balance point of view, this problem can only be solved by reversing the concentrations of the subsystems. The 
proportion of water that in fact needs to be discharged on a daily basis is the key point in this reverse-engineering process, as it defines the process and concentrate flows. For that reason, the RO's efficiency ratio is highly important as it determines the concentration factor of the RAS-derived process water. A 4:1 ratio would mean that $5 \mathrm{~m}^{3}$ of RAS process water would result in $4 \mathrm{~m}^{3}$ of demineralized water and $1 \mathrm{~m}^{3}$ of RAS concentrate for use in the hydroponic system.

The required degree of concentration depends on the chemical content of the RAS water, which is highly dependent on the fish feed composition. This is because the nutrient solution for the plants in the hydroponic sump is a product of the RO concentrate, the RAS-derived process water in the RAS sump, the biofertilizer (in case mineralization UASB reactors constitute a part of the system), and the added nutrients via a nutrient dosing (i.e., fertilizer) unit (see Figs. 2 and 3).

In economic terms, the RO system is highly dependent on the domestic electricity price. Also, one has to consider that electricity consumption increases with higher desired efficiency ratios. Additional costs include the initial investment (i.e., CapEx), maintenance costs, and membrane replacements. Then again, operation expenses are lowered as the need for both freshwater and additional fertilization is reduced to a high degree, as periodical flushing of RAS water is avoided following this RO-based approach. The strongest economic argument, however, is the additional growth rate one can expect compared with state-of-the-art

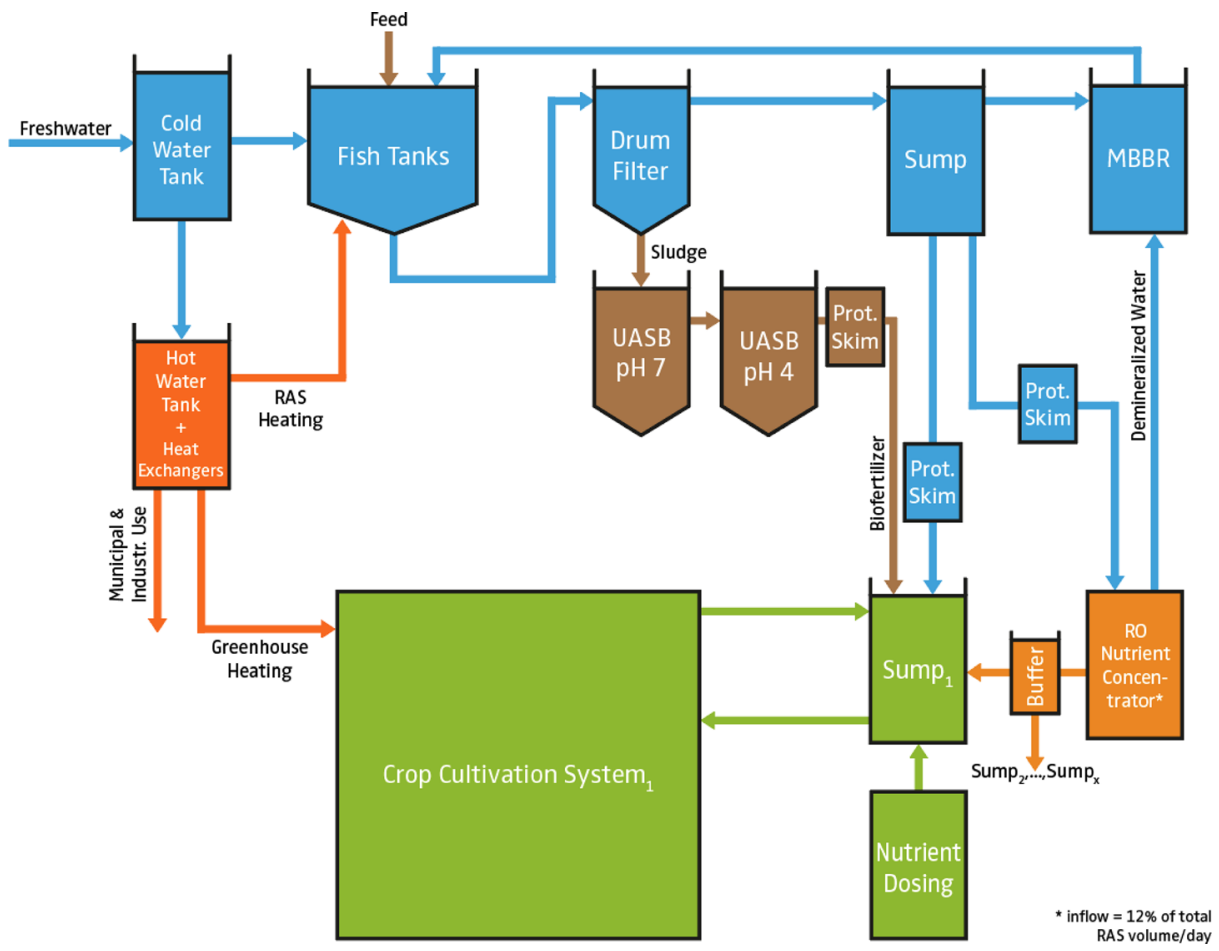

Fig. 3 This aquaponics design extracts the nutrients from the RAS. The nutrient concentrator is consequently RAS-dependent. The concentrated nutrient solution in the buffer can thus be used for several hydroponics subsystems. Also, the low nutrient concentration in the RAS allows for better use of RO technologies 
aquaponics systems (Delaide et al. 2016; Goddek and Vermeulen 2018; Licamele 2009). To what degree the use of RAS-concentrates has an impact on plant growth compared with standard decoupled aquaponics systems (i.e., two loop systems) has yet to be clarified. Another statement that needs to be made is that the bigger the desalination unit, the cleaner the RAS water. Very sensitive fish, for example, could be reared in RAS then. This approach could avoid periodical water bleed-off, resulting in better water and nutrient use efficiency of the overall system.

Determining the financial savings by applying an RO-based nutrient concentrated technology is strongly dependent on the location of the aquaponics system. Location-specific parameters such as water availability, electricity prices, discharge policies/prices, produce market prices, and fertilizer costs determine its economic benefit. However, it is indisputable that the ecological footprint of aquaculture and horticultural production systems can be strongly reduced by closing and optimizing flow and process (control) loops.

\section{Conclusions}

Today, the pressure to find effective strategies for the sustainable transformation of agricultural systems is higher than ever. Combining different production systems and using their respective waste streams to produce more with fewer resources is the concept of aquaponics. In order to be able to survive in the markets, the production needs to be able to keep up with state-of-the-art systems such as hydroponics. Previous studies have shown the tendency that leafy green yields in decoupled aquaponics were at least equivalent to the yields achieved in hydroponics systems. For tomatoes, such an observation was not made so far. However, there is an indication that blossomend rot might occur less under aquaponic conditions (Delaide et al. 2019b; Schmautz et al. 2016). Consequently, this paper showed that loop optimization measures are necessary in order to achieve higher nutrient and water use efficiency and promote sustainable ecological and economic development. This can be achieved by implementing, for instance, RO technologies into decoupled aquaponics systems. Nevertheless, further research is required with respect to the impact of RAS-concentrates on plant growth.

Open Access This article is licensed under a Creative Commons Attribution 4.0 International License, which permits use, sharing, adaptation, distribution and reproduction in any medium or format, as long as you give appropriate credit to the original author(s) and the source, provide a link to the Creative Commons licence, and indicate if changes were made. The images or other third party material in this article are included in the article's Creative Commons licence, unless indicated otherwise in a credit line to the material. If material is not included in the article's Creative Commons licence and your intended use is not permitted by statutory regulation or exceeds the permitted use, you will need to obtain permission directly from the copyright holder. To view a copy of this licence, visit http://creativecommons.org/licenses/by/4.0/.

\section{References}

Al-Karaghouli, A., Kazmerski, L.L., 2012. Comparisons of technical and economic performance of the main desalination processes with and without renewable energy coupling 8

Al-Shammiri M, Safar M (1999) Multi-effect distillation plants: state of the art. Desalination Eur Conf Desalination Environ 126:45-59. https://doi.org/10.1016/S0011-9164(99)00154-X 
Bartman AR, Zhu A, Christofides PD, Cohen Y (2010) Minimizing energy consumption in reverse osmosis membrane desalination using optimization-based control. J Process Control 20:1261-1269. https://oi. org/10.1016/j.jprocont.2010.09.004

Birkett JD (1984) A brief illustrated history of desalination: from the bible to 1940. Desalination 50:17-52. https://doi.org/10.1016/0011-9164(84)85014-6

Boels L, Keesman KJ, Witkamp G-J (2012) Adsorption of phosphonate antiscalant from reverse osmosis membrane concentrate onto granular ferric hydroxide. Environ Sci Technol 46:9638-9645. https://oi. org/10.1021/es302186k

Campbell BM, Vermeulen SJ, Aggarwal PK, Corner-Dolloff C, Girvetz E, Loboguerrero AM, Ramirez-Villegas J, Rosenstock T, Sebastian L, Thornton PK, Wollenberg E (2016) Reducing risks to food security from climate change. Glob Food Secur, 2nd International Global Food Security Conference 11:34 43. https://oi. org/10.1016/j.gfs.2016.06.002

Carmassi G, Incrocci L, Maggini R, Malorgio F, Tognoni F, Pardossi A (2005) Modeling salinity build-up in recirculating nutrient solution culture. J Plant Nutr 28:431-445. https://doi.org/10.1081/PLN-200049163

Chen Y, Baygents JC, Farrell J (2017) Removing phosphonate antiscalants from membrane concentrate solutions using granular ferric hydroxide. J Water Process Eng 19:18-25. https://doi.org/10.1016/j.jwpe.2017.07.002

Delaide B, Goddek S, Gott J, Soyeurt H, Jijakli MH (2016) Lettuce (Lactuca sativa L. var. Sucrine) growth performance in complemented aquaponic solution outperforms hydroponics. Water 8:467. https://doi. org/10.3390/w8100467

Delaide B, Delhaye G, Dermience M, Gott J, Soyeurt H, Jijakli MH (2017) Plant and fish production performance, nutrient mass balances, energy and water use of the PAFF Box, a small-scale aquaponic system. Aquac Eng 78:130-139 10/gbz37j

Delaide B, Monsees H, Gross A, Goddek S (2019a) Aerobic and anaerobic treatments for aquaponic sludge reduction and mineralisation. In: Goddek S, Joyce A, Kotzen B, Burnell GM (eds) Aquaponics food production systems. Springer International Publishing, Cham, pp 247-266. https://doi.org/10.1007/978-3030-15943-6_10

Delaide B, Teerlinck S, Decombel A, Bleyaert P (2019b) Effect of wastewater from a pikeperch (Sander lucioperca L.) recirculated aquaculture system on hydroponic tomato production and quality. Agric Water Manag 226:105814. https://doi.org/10.1016/j.agwat.2019.105814

Dijkgraaf KH, Goddek S, Keesman KJ (2019) Modeling innovative aquaponics farming in Kenya. Aquac Int 27 : 1395-1422. https://doi.org/10.1007/s10499-019-00397-z

Espinal CA, Matulić D (2019) Recirculating aquaculture technologies. In: Goddek S, Joyce A, Kotzen B, Burnell GM (eds) Aquaponics food production systems: combined aquaculture and hydroponic production technologies for the future. Springer International Publishing, Cham, pp 35-76. https://doi.org/10.1007/978-3-030$15943-6 \_3$

Fisher HC (2009) Progress towards biodegradable phosphonate scale inhibitors, in: ResearchGate. Presented at the Conference: 20th International Oil Field Chemistry Symposium, Geilo, Norway

Fried A, Serio B (2012) Water Industry Segment Report Desalination. World Trade Center San Diego, San Diego.

Goddek S, Keesman KJ (2018) The necessity of desalination technology for designing and sizing multi-loop aquaponics systems. Desalination 428:76-85 10/gcxpmg

Goddek S, Vermeulen T (2018) Comparison of Lactuca sativa growth performance in conventional and RASbased hydroponic systems. Aquac Int 26:1377-1386. https://doi.org/10.1007/s10499-018-0293-8

Goddek S, Espinal CA, Delaide B, Jijakli MH, Schmautz Z, Wuertz S, Keesman KJ (2016) Navigating towards decoupled aquaponic systems: a system dynamics design approach. Water 8:303. https://doi.org/10.3390 /w8070303

Goddek S, Delaide BPL, Joyce A, Wuertz S, Jijakli MH, Gross A, Eding EH, Bläser I, Reuter M, Keizer LCP, Morgenstern R, Körner O, Verreth J, Keesman KJ (2018) Nutrient mineralization and organic matter reduction performance of RAS-based sludge in sequential UASB-EGSB reactors. Aquac Eng 83:10-19 $10 /$ gf8qwb

Goddek S, Joyce A, Wuertz S, Körner O, Bläser I, Reuter M, Keesman KJ (2019) Decoupled aquaponics systems. In: Goddek S, Joyce A, Kotzen B, Burnell GM (eds) Aquaponics food production systems: combined aquaculture and hydroponic production technologies for the future. Springer International Publishing, Cham, pp 201-229. https://doi.org/10.1007/978-3-030-15943-6_8

Greenlee LF, Lawler DF, Freeman BD, Marrot B, Moulin P (2009) Reverse osmosis desalination: water sources, technology, and today's challenges. Water Res 43:2317-2348 10/bmjcrn

Howden SM, Soussana J-F, Tubiello FN, Chhetri N, Dunlop M, Meinke H (2007) Adapting agriculture to climate change. Proc Natl Acad Sci 104:19691-19696 10/dpc8xj

Juda W, McRae WA (1950) Coherent ion-exchange gels and membranes. J Am Chem Soc 72:1044-1044. https://doi.org/10.1021/ja01158a528 
Karabelas AJ, Koutsou CP, Kostoglou M, Sioutopoulos DC (2018) Analysis of specific energy consumption in reverse osmosis desalination processes. Desalination, "Desalination, energy and the environment" in honor of Professor Raphael Semiat. 431:15-21. https://doi.org/10.1016/j.desal.2017.04.006

Kledal PR, Thorarinsdottir R (2018) Aquaponics: a commercial niche for sustainable modern aquaculture. In: Hai FI, Visvanathan C, Boopathy R (eds) Sustainable aquaculture, applied environmental science and engineering for a sustainable future. Springer International Publishing, Cham, pp 173-190. https://doi.org/10.1007 /978-3-319-73257-2 6

Kloas W, Groß R, Baganz D, Graupner J, Monsees H, Schmidt U, Staaks G, Suhl J, Tschirner M, Wittstock B, Wuertz S, Zikova A, Rennert B (2015) A new concept for aquaponic systems to improve sustainability, increase productivity, and reduce environmental impacts. Aquac Environ Interact 7:179-192 10/f7vgpc

Lekang O-I (2007) Aquaculture Engineering. Blackwell Publishing Ltd

Lennard WA, Leonard BV (2006) A Comparison of Three Different Hydroponic Sub-systems (gravel bed, floating and nutrient film technique) in an Aquaponic Test System. Aquac Int 14:539-550 10/b8xgh6

Licamele JD (2009) Biomass production and nutrient dynamics in an aquaponics system 172-172

Monsees H, Keitel J, Paul M, Kloas W, Wuertz S (2017a) Potential of aquacultural sludge treatment for aquaponics: evaluation of nutrient mobilization under aerobic and anaerobic conditions. Aquac Environ Interact 9:9-18. https://doi.org/10.3354/aei00205

Monsees H, Kloas W, Wuertz S (2017b) Decoupled systems on trial: eliminating bottlenecks to improve aquaponic processes. PLoS One 12:e0183056. https://doi.org/10.1371/journal.pone.0183056

Nicoletto C, Maucieri C, Mathis A, Schmautz Z, Komives T, Sambo P, Junge R (2018) Extension of aquaponic water use for NFT baby-leaf production: mizuna and rocket salad. Agronomy 8:75. https://doi.org/10.3390 /agronomy 8050075

Nozzi V, Graber A, Schmautz Z, Mathis A, Junge R (2018) Nutrient management in aquaponics: comparison of three approaches for cultivating lettuce, mint and mushroom herb. Agronomy 8:27. https://doi.org/10.3390 /agronomy 8030027

Palm HW, Knaus U, Appelbaum S, Strauch SM, Kotzen B (2019) Coupled Aquaponics systems. In: Goddek S, Joyce A, Kotzen B, Burnell GM (eds) Aquaponics food production systems: combined aquaculture and hydroponic production technologies for the future. Springer International Publishing, Cham, pp 163-199. https://doi.org/10.1007/978-3-030-15943-6 7

Saha S, Monroe A, Day MR (2016) Growth, yield, plant quality and nutrition of basil (Ocimum basilicum L.) under soilless agricultural systems. Ann Agric Sci 61:181-186. https://doi.org/10.1016/j.aoas.2016.10.001

Savvas D, Chatzieustratiou E, Pervolaraki G, Gizas G, Sigrimis N (2008) Modelling Na and Cl concentrations in the recycling nutrient solution of a closed-cycle pepper cultivation. Biosyst Eng 99:282-291. https://doi. org/10.1016/j.biosystemseng.2007.10.008

Schmautz Z, Loeu F, Liebisch F, Graber A, Mathis A, Griessler Bulc T, Junge R (2016) Tomato productivity and quality in aquaponics: comparison of three hydroponic methods. Water 8:533. https://doi.org/10.3390 /w8110533

Singh R (2005) Hybrid membrane systems for water purification - 1st edition. Elsevier Science

Timmons MB, Ebeling JM (2013) Recirculating aquaculture, 3rd edn. Ithaca Publishing Company LLC, Ithaca

Van der Bruggen B, Vandecasteele C (2002) Distillation vs. membrane filtration: overview of process evolutions in seawater desalination. Desalination 143:207-218. https://doi.org/10.1016/S0011-9164(02)00259-X

Vermeulen SJ, Campbell BM, Ingram JSI (2012) Climate change and food systems. Annu Rev Environ Resour 37:195-222. https://doi.org/10.1146/annurev-environ-020411-130608

Wilson JR (1960) Demineralization by electrodialysis. Butterworths Scientific Publications

Yep B, Zheng Y (2019) Aquaponic trends and challenges - a review. J Clean Prod 228:1586-1599. https://doi. org/10.1016/j.jclepro.2019.04.290

Publisher's note Springer Nature remains neutral with regard to jurisdictional claims in published maps and institutional affiliations. 